FACTA UNIVERSITATIS

Series: Law and Politics Vol. 15, N 3, 2017, pp. 235 - 244

https://doi.org/10.22190/FULP1703235A

Review Article

\title{
THE ELEMENTS OF PROPORTIONALITY AS A PRINCIPLE OF HUMAN RIGHTS LIMITATIONS
}

\author{
UDC 342.72/.73 \\ 341.231 .14
}

\section{Luka Anđelković}

Higher Court in Niš, Republic of Serbia

\begin{abstract}
The article discusses the elements of proportionality as the most important requirement that must be satisfied in the limitation of human rights. There are four major elements of this principle: legitimacy, adequacy, necessity, and proportionality stricto sensu. Legitimacy means that limitation must pursue a legitimate aim. Adequacy means that the chosen measure must be suitable for achieving that aim. Furthermore, the government may only use the least restrictive measure for achieving the aim, the one that causes least damage to protected rights and interests. In order to be deemed proportionate, the limitation must satisfy the test of proportionality stricto sensu, which means that achieving a particular aim must be important enough to justify the damage which will be caused to individual rights. This article particularly focuses on the application and the significance of these elements in the case-law of the European Court of Human Rights and the Constitutional Court of Serbia.
\end{abstract}

Key words: proportionality, human rights, limitations, ECtHR

\section{INTRODUCTION}

Most of the fundamental human rights and freedoms are subject to certain limitations. Only a small number of them cannot be restricted under any circumstances (for example: the right to be free from torture). Human rights limitations must fulfil certain conditions in order to be deemed valid. Most importantly, they must comply with the principle of proportionality, which imposes "the boundaries" of human rights' limitations. This article analyses the elements of the principle of proportionality, which comprises four major elements: legitimacy, adequacy, necessity, and proportionality stricto sensu. Besides providing the basic theoretical standpoints on the meaning and the importance of these legal rules, the paper also focuses on the application of these rules in the Serbian and European

Received February 22 nd, $2017 /$ Accepted July $6^{\text {th }}, 2017$

Corresponding author: Luka Anđelković, LL.M, Trainee-volunteer

Higher Court in Niš, Republic of Serbia

E-mail: lukanis92@gmail.com 
jurisprudence. In that regard, the article presents the general principles established in judicial practice and analyzes the cases adjudicated by the European Court of Human Rights and the Constitutional Court of Serbia, where these rules were assessed. Before this analysis, the article briefly explores the origin of applying this principle in the area of human rights, as well as the legal provisions of national and international law which serve as a basis for the application of proportionality principle.

\section{The ORIGIN AND the EVOLUTION OF THE PRINCIPLE OF PROPORTIONALITY}

The principle of proportionality has its roots in legal history and it can be considered as a fundamental concept of justice (Nastić, 2010: 974). In its modern sense, it was created in the late $19^{\text {th }}$ century in the German administrative law in the context of limitation of police powers (Schlink, 2012: 728). At the time, the police had unlimited discretionary powers in performing their tasks. As the idea of individual rights and the idea of "rechtsstaat" emerged, there was a need to limit these police powers. It was done by administrative courts which introduced the principle of proportionality. This principle imposed obligation on the police to use the means which are adequate for achieving the intended aims, to use the means which are least restrictive for the protected rights and interests, and to ensure that the achievement of a particular aim must be important enough to justify such restriction.

The proportionality principle was first applied in the sphere of human rights in the jurisprudence of the German Federal Constitutional Court in the second half of the 20th century (Schlink, 2012: 729). This court had to reconcile the conflicting provisions of the German Basic Law which, on the one hand, guaranteed individual rights and freedoms but, on the other hand, gave the parliament the powers to limit them. There was a need to secure the practical coexistence of these provisions. The solution was found in the principle of proportionality, which means that the measures which interfere with certain human rights or freedoms must be proportionate to the aim they pursue. This was a way to secure the protection against arbitrary limitation of human rights and freedoms (Schlink, 2012: 729).

Today, the principle of proportionality finds its application in many legal areas, such as the use of force and exterritorial jurisdiction (Nastić, 2010: 974). It is applied in the common law and civil law legal systems, as well as in the jurisprudence of many international courts, such as the European Court of Human Rights, the European Court of Justice and the Inter-American Court of Human Rights (Cianciardo, 2010: 177-178).

\section{PROPORTIONALITY IN THE JURISPRUDENCE OF THE EUROPEAN COURT of Human Rights AND THE CONSTITUTIONAL COURT OF SERBIA}

The principle of proportionality is not explicitly mentioned in the European Convention on Human Rights (ECHR). Therefore, its application in the proceedings before the European Court of Human Rights (ECtHR) is a result of this Court's practice. Nevertheless, it may be argued that this principle is implicitly embodied in articles of the Convention which provide that human rights and freedoms may be limited when it is necessary in a democratic society for the protection of certain legitimate aims, since legitimacy and necessity are both elements of this principle.

The European Court of Human Rights mostly refers to this principle when it determines the existence of necessity in a democratic society, in the sense of Articles 8-11 of the 
Convention and Article 2 of Protocol 4 to the Convention. The Court emphasizes that this standard is fulfilled in cases when interference corresponds to a pressing social need ${ }^{1}$, when the reasons adduced by the national authorities to justify it are relevant and sufficient, and when it is proportionate to the legitimate aim pursued. ${ }^{2}$

However, the principle of proportionality is also applied in the context of other rights, such as right to personal liberty, right to access to court, right to free elections, right to property, and prohibition of discrimination. In relation to these rights, the proportionality test is expressed in different ways. In some of the cases, the Court expressly refers to proportionality, stating that the limitation must be proportionate to the legitimate aim and that there must be a reasonable relationship of proportionality between aims and means used. By contrast, in certain cases, the Court refers to the protection of the very essence of the protected right, to the excessive burden which a measure imposes on an individual, as well as to the balance between public interests and individual rights and freedoms (Harbo, 2015:66). While the Court strictly applies the proportionality test when assessing necessity in a democratic society with regard to Articles 8-11 of the Convention, its approach is more flexible regarding other rights and freedoms; in such cases, the Court refers to "a fair balance" and "the very essence of the right" (Nastić, 2010: 980).

The Constitution of the Republic of Serbia does not explicitly mention the principle of proportionality either. However, like the above-mentioned provisions of the European Convention, it envisages in Article 20 that any limitation of human rights must be necessary to meet the purpose of restriction in a democratic society. The same article envisages the duty of courts and other public bodies to consider the substance of the restricted right, the pertinence of restriction, the nature and extent of restriction, the relation between the restriction and its purpose, as well as the likelihood of achieving the purpose of restriction by using less restrictive means. ${ }^{3}$ These constitutional provisions provide the basis for the application of the principle of proportionality in the courts' practice. Therefore, the Constitutional Court of Serbia emphasizes that it has the obligation to determine in each particular case whether the limitation of a specific right was proportionate to the legitimate aims pursued. ${ }^{4}$

\section{ELEMENTS OF THE PRINCIPLE OF PROPORTIONALITY}

Theory traditionally emphasizes three major elements of proportionality: adequacy (sufficiency), necessity, and proportionality in a narrow sense (stricto sensu) (Pejić, 2010: 857). Adequacy means that the measure which limits the right must be adequate for achieving the aim and the desired result (Cianciardo, 2010: 179). Necessity means that the least restrictive measure should be used for achieving the aim. The least restrictive measure is the one that has the least effect on the guaranteed right. Proportionality stricto sensu requires the existence of balance between conflicting rights and interests.

Some authors add the forth rule: the existence of a legitimate aim for limitation (Barak, 2012:132). In the proportionality analysis, this element comes before the above-mentioned elements. The limitation must first pass the legitimacy test so that we can consider its

\footnotetext{
${ }^{1}$ Silver and Others $v$ the United Kingdom, App no 5947/72 6205/73 7052/75 7061/75 7107/75 7113/75 7136/75 (ECtHR, 25 March 1983)

${ }^{2}$ Steel and Morris v. the United Kingdom, App no 68416/01 (ECtHR, 15 February 2005)

${ }^{3}$ Art. 20 para. 3, the Constitution of the Republic of Serbia, Official Gazette RS, 98/2006

${ }^{4}$ Decision of the Constitutional Court of Serbia Už-26/2012
} 
adequacy and necessity. As these standards are inextricably linked, this article accepts the idea of four major proportionality rules.

\subsection{The existence of a legitimate aim for limitation of human rights}

This element reflects the notion that any limitation of human rights has to be justified. The rights and freedoms may be limited only for the purpose of protection of fundamental democratic values in the society (Barak, 2012a: 245).

The European Convention (in Articles 8, 9, 10 and 11, as well as in Article 2 of Protocol 4 to the Convention) explicitly defines the legitimate aims for the limitation of rights enshrined in these articles. Other articles of the Convention do not make such enumeration so that states do not have a limited number of legitimate aims which they may invoke in relation to those articles. $^{5}$

Unlike the European Convention, the Serbian Constitution stipulates in its general provision that human rights may be limited only for the purposes prescribed by the Constitution. ${ }^{6}$ Then, in provisions which guarantee specific rights and freedoms, the Constitution prescribes legitimate aims for limiting each of these rights. After examining the provisions of the European Convention and the Serbian Constitution, we can observe certain legitimate aims which are common to a larger number of guaranteed human rights. They include: the protection of public order, the protection of national security, the interests of defense of the state, the need to conduct criminal proceedings, the protection of the rights and freedoms of others, the protection of health, and the protection of morals in a democratic society. On the other hand, we can single out certain aims which are specific to certain rights and freedoms. Thus, the Serbian Constitution provides that only the freedom of expression may be restricted for maintaining the authority and impartiality of the judiciary ${ }^{7}$, and that only the freedom of movement may be limited in order to prevent the spread of infectious diseases. ${ }^{8}$

The ECtHR took the general stance that the provisions which prescribe legitimate aims for the limitation of human rights must be narrowly construed, since these provisions represent an exception to the general rule which provides protection of a certain right. ${ }^{9}$ However, in a very small number of its judgments, the Court found that restrictions of certain rights do not pursue any of the prescribed legitimate aims. Some authors emphasize that the prescribed list of legitimate aims is broad enough to cover nearly every government activity, while the ECtHR itself has interpreted these aims broadly and freely (Schabas, 2015: 404). Other authors point out that no democratic country wants to be held liable for explicitly or implicitly introducing arbitrary goals into its legislation, and argue that the Court usually assesses the fulfillment of this requirement together with the analysis of other elements of the proportionality principle (Arai, Arai-Takahashi, 2001: 11).

This is affirmed by the ECtHR case-law. The case of Baka v. Hungary ${ }^{10}$ concerned the change of the rules on the election of the president of the highest court in the country for the purpose of replacing the current president (the applicant), due to his statements on

\footnotetext{
${ }^{5}$ Hirst v. the United Kingdom (no. 2), App no 74025/01 (ECtHR, 6 October 2005)

${ }^{6}$ Art. 20 para. 1, the Constitution of the Republic of Serbia, Official Gazette RS, 98/2006

${ }^{7}$ Art. 46 para. 2, The Constitution of the Republic of Serbia, Official Gazette RS, 98/2006

${ }^{8}$ Art. 39 para. 2, the Constitution of the Republic of Serbia, Official Gazette RS, 98/2006

${ }^{9}$ Perinçek v. Switzerland, App no 27510/08 (ECtHR, 15 October 2015)

${ }^{10}$ Baka v. Hungary, App no 20261/12 (ECtHR, 23 June 2016)
} 
the reform of the judiciary. The Court found that there had been an interference with his freedom of expression. The state invoked maintaining the authority and impartiality of the court as a legitimate aim for such interference. The Court concluded that there is no legitimate aim for interference in the particular case. While this was enough for the Court to find a violation of the applicant's freedom of expression, the Court held that it was necessary to examine whether the third and the most important requirement under Article 10 of the Convention was fulfilled, i.e. whether the impugned measure was necessary in a democratic society.

A broad interpretation of the legitimate aims may be illustrated by the ECtHR judgment in the case of S.A.S. v. France. The applicant was a Muslim woman who complained about the enactment of legislation which prohibited women to cover their faces in public. She argued that the legislation violated her right to respect for private life and her freedom of religion, given that she wears a niqab over her face in public for religious reasons. The Court found that this measure pursued a legitimate aim of protecting the rights and freedoms of others, namely, the protection of the rights of others to live in a space which facilitates socialization and coexistence. Furthermore, the Court found that the said measure was proportionate to the legitimate aim, and that there was no violation of any right protected by the Convention. This stance was criticized in the dissenting opinion of two judges who stated that the disputed measure did not correspond to any legitimate aim since it cannot be argued that there is a right to enter into communication with other people in public against their will. ${ }^{11}$

\subsection{Adequacy of limitation}

Adequacy of limitations of human rights requires the existence of a reasonable connection between a legitimate aim and the means used for accomplishing the aim pursued. The limitation of a right in each particular case must be appropriate for accomplishing the legitimate aim. In relation to this requirement, there is an issue of the necessary level of certainty that a measure will contribute to achieving a certain aim. Many of the human rights limitations are imposed on the basis of prediction of economic, social and political developments in the future. Therefore, there is often a level of uncertainty regarding their effectiveness. Taking this fact into account, it is necessary to take a slightly more flexible stance on this issue which would not require a complete certainty regarding efficiency of measures, but which would require the existence of a certain level of probability that a certain legitimate aim will be achieved (Barak, 2012a:310).

There is a small number of cases in which the European Court of Human Rights called upon this standard. The case of Perinçek $v$. Switzerland is one of the few judgments in which the Court expressly relied on this standard. The applicant, a Turkish politician, was convicted in Switzerland because he had denied the existence of the Armenian genocide at certain public gatherings in this country. The Grand Chamber of the European Court of Human Rights ruled in his favor, calling upon (among other things) the lack of adequacy of limitation. The Court pointed out that the principle of proportionality requires the existence of reasonable connection between the measures taken by the public authorities and the aim which these measures seek to achieve, in the sense that there must be a reasonable possibility that the actions taken will produce the desired result. In the present case, the

\footnotetext{
${ }^{11}$ S.A.S. v. France, App no 43835/11 (ECtHR, 1 July 2014)
} 
hatred against the Armenian minority in Turkey could not be regarded as a consequence of a statement given by the applicant in Switzerland, nor could it be considered that the applicant's conviction in Switzerland could indeed serve to protect the rights of the Armenian minority in Turkey. ${ }^{12}$

An interesting analysis of the adequacy principle is found in the Grand Chamber's judgment in the case of Hirst $v$. the United Kingdom (no. 2). ${ }^{13}$ The applicant was a prisoner who complained about the general rule on forfeiture of the right to vote to all prisoners while they are serving a sentence. In the proceedings before the Court, the respondent state pointed out that this measure sought to prevent crime, increase civic responsibility and ensure respect for the rule of law. The Court concluded that there was no evidence that the disenfranchisement of prisoners leads to the reduction of crime, as well as that there is not a clear and logical link between these measures and the aims of enhancing civic responsibility and the rule of law. Despite expressing doubts about the adequacy of these measures, the Court left the issue open. In further analysis, the Court found that the contested measures did not fulfill other requirements of the principle of proportionality, and concluded that the State had violated the right to free elections under Article 3 of Protocol No. 1 to the Convention.

\subsection{Necessity of limitation - the standard of the least restrictive measure}

The European Court of Human Rights and the Constitutional Court of Serbia often refer to the standard of necessity of human rights limitations or the principle of using the least restrictive measure for achieving the legitimate aim. In the ECtHR case-law, it is emphasized that a measure is proportionate in cases when there is no possibility of recourse to an alternative measure which would cause less damage to the fundamental right in issue whilst fulfilling the same aim. ${ }^{14}$ The Serbian Constitutional Court has held that an interference with a fundamental right is justified when the legitimate aim could not be achieved to the same extent in contemporary social circumstances by using a different, less restrictive measure. ${ }^{15}$ When assessing whether a certain measure is less restrictive than another one, courts should take into account the extent of these measures, their effects, duration, as well as probability that these measures would affect the guaranteed right (Barak, 2012a: 326). It is crucial that courts evaluate proportionality of a measure from the point of an individual whose right is limited and not from the point of the aim which is sought to be achieved (Schlink, 2012:724).

The European Court of Human Rights found a violation of this principle in the case of Sejdic and Finci v. Bosnia and Herzegovina. ${ }^{16}$ The applicants were a Roma and a Jew who claimed to have been barred from being elected to the House of Nations and the Presidency of Bosnia and Herzegovina, as this right is reserved only for members of the constituent nations. The Court ruled in their favor finding that there are other ways to achieve the aim of separation of political powers between the constituent nations in Bosnia and Herzegovina, while at the same time preserving the participation of other nationalities in the

\footnotetext{
${ }^{12}$ Perinçek v. Switzerland, App no 27510/08 (ECtHR, 15 October 2015)

${ }^{13}$ Hirst v. the United Kingdom (no. 2), App no 74025/01 (ECtHR, 30 March 2004)

${ }^{14}$ Nada v. Switzerland, App no 10593/08 (ECtHR, 12 September 2012)

${ }^{15}$ Decision of the Constitutional Court of Serbia IУ

${ }^{16}$ Sejdić and Finci v. Bosnia and Herzegovina, App nos 27996/06 34836/06 (ECtHR, 22 December 2009)
} 
legislative and executive bodies. On the other hand, in the case of Uzun v. Germany ${ }^{17}$, the Court concluded that the authorities acted in accordance with the principle of proportionality. The applicant in this case was suspected of and later convicted for committing a series of bomb attacks carried out in Germany. In order to collect evidence against him, the authorities planted a GPS receiver in his car. The applicant alleged that this measure represented a violation of his right to privacy. Regarding these allegations, the Court took into account that the authorities initially tried to follow the applicant by using other means which affected his privacy to a lesser extent. They originally installed a transmitter in his car, whose use (unlike the use of GPS) requires knowledge of the approximate location of the followed person. However, the applicant found and destroyed the transmitter, and he also successfully avoided visual monitoring by state agents. For these reasons, the national authorities rightfully concluded that it was necessary to plant a GPS receiver in his car, having in mind that the less restrictive measures proved to be inefficient.

As regards the practice of the Constitutional Court of Serbia, one of the most illustrative examples of the application of this standard was the decision VIIY-249/2009 on the prohibition of work of the ultra-nationalist organization "Obraz" (Patriotic Front Dignity). The work of this association was prohibited on account of its activities aimed at breaching the guaranteed human and minority rights and inciting national and religious hatred. In the reasoning of its decision, the Constitutional Court emphasized that that the Serbian authorities, police, public prosecutors and courts, had already taken a series of measures to prevent the illegal behavior of the members of this association. These activities were reflected in a number of initiated criminal and misdemeanor proceedings, some of which resulted in convictions. However, despite the measures of competent authorities, the association continued with activities aimed at violating the basic human rights and freedoms and inciting national and religious hatred. Therefore, the Constitutional Court concluded that less restrictive measures were not sufficient for the protection of the legitimate aim, and that it was necessary to impose the most rigorous measure in the field of restricting the freedom of association. $^{18}$

\subsection{Striking a balance between competing rights and interests}

If a measure of the national authorities represents the least restrictive method for achieving certain legitimate aim, courts should move to the analysis of the next element of the proportionality principle: proportionality stricto sensu or striking a balance between competing rights and interests in a particular case. The test of proportionality stricto sensu supplements the standard of the least restrictive means, but differs from it. While the standard of the least restrictive means considers the efficiency of the means used for achieving the legitimate aim pursued, the test of proportionality stricto sensu represents a kind of costbenefit analysis of a particular limitation. It is often depicted by a pair of scales, one of which weighs the benefits while the other one measures what is lost due to the restriction.

Legal writers try to explain the test of proportionality stricto sensu in different ways. Aharon Barak states that it is a matter of comparing certain factors. On the one hand, courts have to assess the legitimate aim to be achieved, its importance and urgency, the benefits that can be gained, and the likelihood of achieving such benefits. On the other

\footnotetext{
${ }^{17}$ Uzun v. Germany, App no 35623/05 (ECtHR, 2 September 2010)

${ }^{18}$ Decision of the Constitutional Court of Serbia VIIY-249/2009, Official Gazette RS, 69/2012
} 
side of the imaginary scales, there is a right which is subject to restriction, the damage that is caused by the interference and the likelihood that such damage will actually be caused (Barak, 2012a: 348). However, we must determine the rules, on the basis of which these elements should be "weighed". Barak further argues that the result largely depends on the importance of the limited right. Namely, all fundamental rights do not have the same value. Their social importance and value that people attach to them varies from country to country. Moreover, certain rights are more important than others since their exercise and observance represents a precondition for exercising other rights. In addition to the importance attached to the limited right, the decision depends on the nature of restriction, its duration, scope and rigor (Barak, 2012b: 745-746).

Robert Alexy describes the test of proportionality stricto sensu in three simple steps (Schlink: 2012: 726). In the first step, the court determines the damage which will be sustained by one party if the other party prevails. In the second step, the court determines the possible damage to the other party if priority is given to the first party. In the third step, courts should decide whether giving advantage to one party justifies the damage caused to the other party. Although there are different standpoints in regard to the implementation of this test, there is an inevitable conclusion that the final decision to give priority to one of the parties in the dispute is subjective in its nature. When making this decision, courts must take into account all the relevant facts, interests, rights, principles, social values, as well as relevant case law (Schlink: 2012: 726).

With regard to this element of the proportionality principle, the European Court of Human Rights noted that, when analyzing the justification of restrictions on rights, it is essential to assess whether the authorities struck a fair balance between the competing public and private interests. ${ }^{19}$ The application of this standard is found in the case of Rodrigues da Silva and Hoogkamer v. the Netherlands. ${ }^{20}$ The applicant was a Brazilian citizen who illegally moved to the Netherlands. In this country, she had a child with her Dutch extramarital partner. The couple separated after a few years and the applicant's partner was awarded custody over their child. At the same time, the applicant's request for residence permit in the Netherlands was rejected on the grounds that the protection of the economic well-being of the state overrides all the other relevant interests in this case. The ECtHR ruled that the right to respect for family life of the applicant and her daughter was violated, as it was clear that it was in the best interests of the child to live with and be raised by her mother in the same country. For this reason, the Court concluded that the protection of the economic well-being of the country cannot override the rights and interests arising from the relationship between the applicant and her daughter in the particular case.

Similarly to the stance of the European Court of Human Rights, the Serbian Constitutional Court points out that, in a situation where there are two or more conflicting rights or interests whose enjoyment is guaranteed by the Constitution, courts have the task to establish a balance between these conflicting rights appreciating the circumstances of the case. If they decide that one right should prevail over the other one, they have to give detailed reasoning for their decision, especially taking into account the nature, content and limits of those rights. ${ }^{21}$ In the case Už-5436/2010, the Constitutional Court had to decide on the alleged violation of freedom of assembly of union members who were protesting in front of a public institution.

\footnotetext{
${ }^{19}$ Evans v. the United Kingdom, App no 6339/05 (10 April 2007)

${ }^{20}$ Rodrigues da Silva and Hoogkamer v. the Netherlands, App no 50435/99 (ECtHR, 31 January 2006)

${ }^{21}$ Decision of the Constitutional Court of Serbia Už-1123/2009
} 
In misdemeanor proceedings, they were convicted of violating public order and peace, disturbing tranquility and work of employees, due to the fact that they were shouting and calling out the name of one of the officials in a protest which had already lasted for three months. The Constitutional Court emphasized that its task was to assess whether the protest by shouting endangered the rights of others, and whether the tranquility of citizens and the work of employees in public institutions is more important than the protesters' freedom of assembly. The Constitutional Court upheld the applicants' complaints and concluded that freedom of assembly and the right to protest and express disagreement with certain actions is more primary and more important than the interests of other citizens in tranquility and undisturbed activities, without determining whether these interests were really affected in the case.

\section{CONCLUSION}

Proportionality is the most important standard which must be satisfied with regard to human rights restrictions. It is the substantive requirement as it defines how far governments may go in limiting fundamental rights and freedoms. In this article, we have examined the four major elements of proportionality: legitimacy, adequacy, necessity, and proportionality stricto sensu. We may conclude that these elements do not have the same importance in the European and the national jurisprudence. The European Court of Human Rights and the Constitutional Court of Serbia usually focus on analyzing the last two elements. For these reasons, there are not many decisions in which these courts found violations of human rights due to the lack of legitimacy or adequacy of limitation.

The principle of proportionality is often criticized in theory as its requirements are not precise enough. Indeed, especially when assessing the balance of competing rights and interests, courts state that their task is to take into account the nature and significance of the protected rights and the nature and extent of limitations. This means that judicial decisions are inevitably based on the subjective judicial evaluation of these factors in each particular case. However, the need to assess all the relevant factors in each particular case is the key requirement of the principle of proportionality. For this reason, it is difficult to create more precise rules which could be automatically applied in different cases.

\section{REFERENCES}

Arai Y., Arai-Takahashi Y., (2001), The Margin of Appreciation Doctrine and the Principle of Proportionality in the Jurisprudence of the ECHR, Intersentia, Antwerpen - Oxford - New York

Barak A., (2012a), Proportionality: Constitutional Rights and their Limitations, Cambridge University Press, New York

Barak A. (2012b), Proportionality (2); in: Rosenfeld M. and Sajó A., (eds.), The Oxford Handbook of Comparative Constitutional Law, Oxford, 2012, Oxford University Press, pp. 738-755;

Harbo T., (2015), The Function of Proportionality Analysis in European Law, Koninklijke Brill NV, Leiden

Cianciardo J., (2010), The Principle of Proportionality: The Challenges of Human Rights, 3 Journal of Civil Law Studies (2010), available at: http://digitalcommons.law.lsu.edu/jcls/vol3/iss1/11

Schabas W., (2015), The European Convention on Human Rights: A Commentary, Oxford University Press, Oxford

Schlink B., Proportionality (1); in: Rosenfeld M. and Sajó A., (eds.), The Oxford Handbook of Comparative Constitutional Law, Oxford, 2012, Oxford University Press, 718-737 
Настић М., (2010), Принцип пропорционалности у пракси уставних судова и Европског суда за људска права (The principle of proportionality in the jurisprudence of constitutional courts and the European Court of Human Rights), Правни живот, vol. 12/2010, pp. 973-986

Пејић И., (2010), Уставна јемства и „границе“ ограничења људских права (Constitutional guarantees and the boundaries of human rights limitations), Правни живот, vol. 12/2010, pp. 851-864

Case-law of the European Court of Human Rights:

1. Baka v. Hungary, App no 20261/12 (ECtHR, 23 June 2016)

2. Evans v. the United Kingdom, App no 6339/05 (10 April 2007)

3. Hirst $v$. the United Kingdom (no. 2), App no 74025/01 (ECtHR, 6 October 2005)

4. Nada v. Switzerland, App no 10593/08 (ECtHR, 12 September 2012)

5. Perinçek v. , App no 27510/08 (ECtHR, 15 October 2015)

6. Rodrigues da Silva and Hoogkamer v. the Netherlands, App no 50435/99 (ECtHR, 31 January 2006)

7. S.A.S. v. France, App no 43835/11 (ECtHR, 1 July 2014)

8. Sejdic and Finci v. Bosnia and Herzegovina, App nos 27996/06 34836/06 (ECtHR, 22 December 2009)

9. Silver and Others $v$ the United Kingdom, App no 5947/72 6205/73 7052/75 7061/75 7107/75 7113/75 7136/75 (ECtHR, 25 March 1983)

10. Steel and Morris v. the United Kingdom, App no 68416/01 (ECtHR, 15 February 2005)

11. Uzun v. Germany, App no 35623/05 (ECtHR, 2 September 2010)

Decisions of the Constitutional Court of Serbia:

1. Decision of the Constitutional Court of Serbia IУ $3-27 / 2009$

2. Decision of the Constitutional Court of Serbia Už-1123/2009

3. Decision of the Constitutional Court of Serbia Už-26/2012

4. Decision of the Constitutional Court of Serbia VIIY-249/2009, Official Gazette RS, 69/2012

\section{ELEMENTI PROPORCIONALNOSTI KAO PRINCIPA OGRANIČENJA LJUDSKIH PRAVA}

Tema ovog članka jesu elementi proporcionalnosti kao jednog od najvažnijih uslova koji mora biti zadovoljen prilikom ograničenja ljudskih prava. Četiri su glavna elementa ovog principa: legitimnost, adekvatnost, neophodnost i proporcionalnost u užem smislu. Legitimnost znači da ograničenje mora pratiti legitiman cilj. Adekvatnost podrazumeva da izabrana mera mora biti odgovarajuća za ostvarivanje legitimnog cilja. Dalje, vlasti moraju koristiti najmanje restriktivnu meru za ostvarenje cilja, onu koja čini najmanje štete garantovanim pravima i interesima. Konačno, ograničenje mora proći test proporcionalnosti u užem smislu, što znači da ostvarivanje pojedinog cilja mora biti dovoljno važno da opravda štetu koja se na taj način čini individualnim pravima. U suprotnom, ograničenje se neće smatrati proporcionalnim. Clanak posebno analizira primenu $i$ značaj navedenih faktora u praksi Evropskog suda za ljudska prava i Ustavnog suda Srbije.

Ključne reči: proporcionalnost, ljudska prava, ograničenja, Evropski sud za ljudska prava 